\title{
Entomopatogen nematode exploration and virulency against Spodoptera frugiperda J.E Smith
}

\author{
Winda Septi Hade ${ }^{1}$, Djamilah ${ }^{1}{ }^{*}$, Priyatiningsih ${ }^{1}$ \\ Limun, Bengkulu, Indonesia \\ *Corresponding author: miming1605@gmail.com
}

Departement of Plant Protection, Faculty of Agriculture, Universitas Bengkulu, Kandang

\begin{abstract}
Corn (Zea mays L) is a very important food and animal feed after rice. One of the important pests that attack corn plants is Spodoptera frugiperda J.E Smith. This pest is a new pest and is a major pest in corn. In pest control, farmers generally use synthetic chemicals. In an effort to reduce these negative impacts synthetic chemical, entomopathogenic nematode (NEP) was chosen as one of the more environmentally friendly control techniques. This study aims to obtain NEP isolates, population density and virulence against $S$. frugiperda. This research was conducted at the Plant Protection Laboratory, Bengkulu University from December 2019 to April 2020. This study used a Factorial Completely Randomized Design (CRD) with 4 treatments and 5 replications. The treatments consisted of NEP concentrations : $0 \mathrm{Jl} / \mathrm{ml} ; 200 \mathrm{Jl} / 1 \mathrm{ml} ; 400 \mathrm{Jl} / 2 \mathrm{ml} ; 600 \mathrm{Jl} / 3 \mathrm{ml}$ originating from Bengkulu and Kepahiang isolates. Each experiment consisted of 3 S. frugiperda larvae. The results showed that the NEP obtained from each region, namely the genus Steinermatidae. Population density of 9,005 NEP / $5 \mathrm{ml}$ in the Kepahiang area and 6,837 NEP / 5ml in the Bengkulu region. NEP virulence test against $S$. frugiperda larvae showed that $200 \mathrm{Jl} / \mathrm{ml}$ concentration was able to control $S$. frugiperda in maize, and can kill pests within 4 days. With an LC50 value of $163.5 \mathrm{Jl} / \mathrm{ml}$ in Kepahiang isolates and $186.5 \mathrm{Jl} / \mathrm{ml}$ in Bengkulu isolates.
\end{abstract}

Key words: Steinermatidae sp (NEP), S. frugiperda

Reference to this paper should be made as follows :

Hade, W. S., Djamilah, and Priyatiningsih. 2020. Entomopatogen nematode exploration and virulency against Spodoptera frugiperda J.E Smith. Agritropica: Journal of Agricultural Science. 3(2): 70-81. Doi: https://doi.org/10.31186/Jagritropica.3.2.70-81

\section{INTRODUCTION}

Cornworm Spodoptera frugiperda J. E. Smith is an invasive insect that has become a pest on maize (Zea mays) in Indonesia. This insect originates from America and has spread in various countries. In early 2019, this pest was found in maize plants in the Sumatra area (Kementerian Pertanian, 2019). S. frugiperda is also found in maize plants in Bengkulu (Nadrawati et al., 2019).

These pests attack plant growing points which can result in failure of shoot formation. S. frugiperda larvae have a high ability to eat. Larvae will enter the plant and actively eat there, so that if the population is still small it will be difficult to detect. Imago is a strong flier and has a high cruising range (CABI, 2019). Spodoptera frugiperda is polyphagous, some of the main hosts are food plants from the Graminae group such as maize, rice, wheat, sorghum, and sugarcane so that the existence and development of the population is very concerned. The losses incurred due to this pest attack on maize crops in African and European countries are between 8.3 and 20.6 million tons per year with an economic loss of between US \$ 2.5-6.2 billion per year (FAO \& CABI, 2019). The control of $S$. frugiperda 
generally uses synthetic insecticides. The use of insecticides by farmers is generally very intensive, using either single or mixed insecticides, high doses, scheduled spraying, and short-term spraying intervals, which are 2-3 days (Koster, 1990; Buurma and Nurmalinda, 1994). Intensive use of insecticides is irrational, inefficient, and has the potential to cause negative impacts on the environment and the emergence of pest resistance to insecticides (Djunaedi, 2009). Therefore, an effective and efficient control technique is needed in controlling $S$. frugiperda. In addition, control must also be environmentally friendly and not cause resistance, namely by using biological control. One of the most effective biological agents is the use of entomopathogenic nematodes.

Nematodes are worm-like organisms with a size of 700-1200 microns and are in the soil. Among the nematodes found in the soil, some are free-living (nonparasitic), plant parasitic nematodes and insect parasitic nematodes, known as entomopathogenic nematodes (NEP) (Nugrohorini, 2010).

There are two NEP families that act as biological control agents, namely Steinernematidae and Heterorhabditidae. NEP infects its host insects by symbiosis with bacteria in their digestive tract. The nematodes of the Steinernematidae family have symbiosis with the bacteria Xenorhabdus sp and the nematodes of the Heterorhabditidae family have a symbiosis with the genus Photorabdus sp (Smart, 1995).

The entomopathogenic nematode which has high pathogenicity to its host is Steinernema spp. and Heterorhabditis spp. Both types of NEP have the potential to control insect pests of the order Lepidoptera, Coleoptera and Diptera (Chaerani, 1995). Both types of
NEP have been widely studied for their effectiveness in controlling horticultural, food and plantation pests that can cause high mortality (Sulistiyanto, 2008).

NEP is a parasite that specifically attacks insect larvae so it is safe for animals and plants. The use of NEP has a great opportunity to control insect pests. The advantage of NEP over other biological agents is that it is easily found in all soils in many areas, in addition to the ease with which NEPs adapt and survive. Thus, gradually, efforts to use synthetic chemical pesticides have decreased and have begun to shift to controlling the biological agent NEP which is safe for the environment (Ria, 2014).

This study aims to obtain the genus NEP, population density and effective density to kill S. frugiperda.

\section{RESEARCH METHOD}

The research was carried out from December 2019 to April 2020 at the Laboratory, Plant Protection, Faculty of Agriculture, Bengkulu University.

The tools used are a small shovel, tape measure or ruler, binocular stereo microscope, $9 \mathrm{~cm}$ diameter petri dishes and $14 \mathrm{~cm}$ petri dishes, nematode counter plates, hand counters, tweezers, basins, rubber bands, plastic jars, nematode fishing rods, pipettes, $10 \mathrm{ml}$ injection, glass object, label paper, plastic bag, scale, scissors.

The materials used include gauze, filter paper, 3rd instar S. frugiperda larvae, Hong Kong caterpillar (Tenebrio molitor), soil samples, distilled water, $70 \%$ alcohol, formal glyserin fixative (Formalin 40\% $10 \mathrm{ml}, 6 \mathrm{ml}$ glycerol and distilled water $84 \mathrm{ml}$ ), glycerol, methylene blue, and polish.

This research method used exploratory methods and virulence test 
for entomopathogenic nematodes. The exploratory method was carried out in 2 different areas, namely Kepahiang (highlands) and Bengkulu (lowlands) using a sampling technique where each area was taken 5 points for sampling. Virulence test for entomopathogenic nematodes against $S$. frugiperda used a completely randomized design (CRD) with 2 factors, namely:

Factor 1: the origin of the isolate $(\mathrm{W} 1=$ Kepahiang)

$$
\begin{aligned}
& (\mathrm{W} 2=\text { Bengkulu }) \\
& \text { Factor } 2 \text { : concentration }(\mathrm{K} 0= \\
& \text { Control }) \\
& (\mathrm{K} 1=200 \mathrm{Jl} / \mathrm{ml}) \\
& (\mathrm{K} 2=400 \mathrm{Jl} / \mathrm{ml}) \\
& (\mathrm{K} 3=600 \mathrm{Jl} / \mathrm{ml})
\end{aligned}
$$

Each treatment consisted of 5

replications and each experiment consisted of $3 \mathrm{~S}$. frugiperda larvae so that 40 experimental units were obtained.

This research was conducted in several stages. These stages include multiplication of $S$. frugiperda larvae, soil sampling, isolation of entomopathogenic nematodes, white trap method, identification of entomopathogenic nematodes, calculation of population density and nematode application.

Larvae of $S$. frugiperda instar 2, 3 and 4 were collected from maize fields according to the number of needs. Then they are kept in plastic cups and given fresh baby corn as food so they don't get stressed and die. The larvae were maintained until they became pupae and immago, then the immago was transferred to 5L plastic jars that had been given $10 \%$ honey, fresh corn leaves and white oil paper as the media for laying eggs. The eggs are reared until they hatch and become larvae, larvae are maintained up to instar 3, because larvae in instar 3 are the most active larvae in destroying corn plants.
Soil is taken from around the roots of the corn plant. Each location is assigned 5 places randomly. Soil sampling was carried out to a depth of $20 \mathrm{~cm}$. Soil samples were taken using a shovel. Then the soil samples are stored in plastic bags with holes for ventilation (Baliadi, 2011).

Entomopathogenic nematodes were isolated using larvae of Hong Kong caterpillar (Tenebrio molitor). Soil samples taken from 10 location points from 2 regions were put into different basins, each basin was given $20 \mathrm{~T}$. molitor larvae every day sprayed with distilled water to maintain humidity. After 7 days, the dead larvae were removed and rinsed with distilled water. The entomopathogenic nematode trapping was then continued using the White trap extraction method.

The dead larvae showing brown or red symptoms are taken and arranged in large petri containing small petri which is turned over and given filter paper that sticks out to the bottom of a large petri filled with water to half the height of the small petri. The dead larvae are incubated for 7-14 days at $25^{\circ} \mathrm{C}$ and the nematodes will come out down into the water. The $30 \mu$ sieve is used to separate the insect tissue from the nematodes by leaving the filter underneath propped up for a few minutes in a large petri. Storing the nematodes in a specimen container / bottle at 4 oC for 5 days for application (Sulistiyanto, 2011).

Observation on host insects serves to see symptoms of attack by insect parasitic nematodes on the cuticle area which is indicated by a change in color. If the insect's body is brownish black / caramel, it means that the insect is infected with Steinernematidae, and reddish in color if it is infected with Heterorhabditidae. This is caused by the 
reaction of the symbiont bacteria, Xenorhabdus spp. or Photorhabdus spp. which is released by the nematode while inside the host insect.

NEP identification is carried out morphologically, namely by observing the morphology of the nematodes using a binocular microscope, including observing the nematode's body size, head shape, hooks on the head and longitudinal striations on the nematode's body.

Calculation of the population density of entomopathogenic nematodes using a binocular microscope, count plates and hand counters. Then calculated using the formula:

$$
\mathrm{P}=\underline{\mathrm{P} 1+\mathrm{P} 2+\mathrm{P} 3+\mathrm{P} 4+\mathrm{P} 5} x \mathrm{X}
$$

$\mathrm{n}$

Information :

$\mathrm{P}=$ Population of nematodes per... .ml

$\mathrm{n}=$ number of repetitions $\mathrm{P} 1, \ldots \mathrm{P} 5$

$\mathrm{X}=$ volume of suspension / volume of sub samples

Virulence test was carried out with filter paper placed on a petri dish. Before being used, the plates are sterilized in an autoclave with a pressure of $120 \mathrm{~atm}$. Place 1 larvae of 3rd instar $S$. frugiperda into a petri dish. Then the entomopathogenic nematode isolates with a concentration of $200 \mathrm{Jl} / 1 \mathrm{ml}, 400$ $\mathrm{Jl} / 2 \mathrm{ml}$ and $600 \mathrm{JI} / 3 \mathrm{ml}$ distilled water were inoculated into the cup. In control, larvae were applied with sterile distilled water. Larvae were given fresh baby corn feed and maintained at room temperature. Observations of the number of dead $S$. frugiperda and movement of sick $S$. frugiperda and changes in appearance were carried out every 24 hours for 7 days. The percentage of mortality is calculated using the following formula:

$$
\% \text { Mortality }=\frac{\sum \text { dead larvae }}{\sum \text { test larvae }} \times 100 \%
$$

1. Observations were made every 24 hours for 7 days. The variables observed were: Symptoms and signs of infected $S$. frugiperda larvae. Observations were made one day after application (HSA).

2. The feeding power of larvae. The feeding power of larvae will be calculated by weighing 3 grams of baby corn first, then weighing it again every 24 hours. Observation of larval feeding capacity was carried out one day after application (HSA).

3. Percentage of $S$. frugiperda larvae mortality was carried out one day after application (HSA). The percentage of larval mortality is calculated using a formula

$$
P=\frac{\mathrm{a}}{\mathrm{a}+\mathrm{b}} \times 100 \%
$$

Information:

$\mathrm{P}=$ percentage of test insect mortality

$\mathrm{a}=$ number of test insects that died

$\mathrm{b}=$ number of test insects that are still alive

4. The time of death for S. frugiperda larvae after application was calculated from one day after application to the 7th day after application. The time of death for larvae is calculated using the formula:

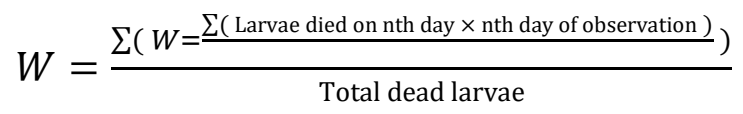

Information:

$\mathrm{W}=$ mean time to death of larvae.

The research data will be analyzed statistically using factorial RAL analyzed with ANOVA level of 5\%, Probit analysis LC50\% and LC75\%. Then if the results are significantly different, a 
further test will be carried out with the LSD test at the $5 \%$ level.

\section{RESULTS AND DISCUSSION}

Symptoms and Signs of $S$. frugiperda Larvae Infected with NEP

Symptoms in larvae infected with NEP show a change in the color of the cuticle of the larvae from green to blackish brown and the movement of the larvae, which initially moved actively, but gradually became slow. When infected larvae die, their bodies become flaccid (Figure 1). If the body of the larva is pressed by hand, it will easily crumble and release a foul-smelling liquid.

The symptoms of these changes have been reported by Djamilah et al., (2010) on Spodoptera litura, that S. litura infected with Steinernema shows several symptoms, namely the movement of the larvae becomes inactive or moves slowly. When touched, the larvae show a different response from healthy larvae, the larvae become limp and over time the larva's body will become more flaccid and change color, the longer the larvae blacken all over its body. When pressed, the larva's body will break easily and release a foul-smelling, yellowish white liquid. Color changes that occur in insects are caused by a symbiotic mutualism between nematodes and bacteria that produce exotoxins.

The activity of $S$. frugiperda larvae infected with entomopathogenic nematodes will reduce their activity and will die due to the toxins released by the symbiont bacteria that live in the digestive tract of the nematodes. According to Gaugler and Kaya (1990), the nematodes of the Steinermatidae family have a symbiosis with the genus Xenorabdus bacteria and the nematodes of the Heterorhabditidae family have symbiosis with the genus Photorhabdus bacteria. These bacteria play a role in killing host insects quickly, within 2-3 days. The death of many host insects is caused by toxins released by bacteria. Bacteria will grow rapidly in the body of the dead host insect and use it as a nutrient. In principle, nematodes feed on these bacteria.

The results of NEP isolation from maize fields in the Kapahiang and Bengkulu regions showed that the characteristics of $T$. molitor larvae that were parasitized by NEP had decreased movement activity, tended to remain stationary, and eventually the larvae would die with blackish brown skin (Figure

2).

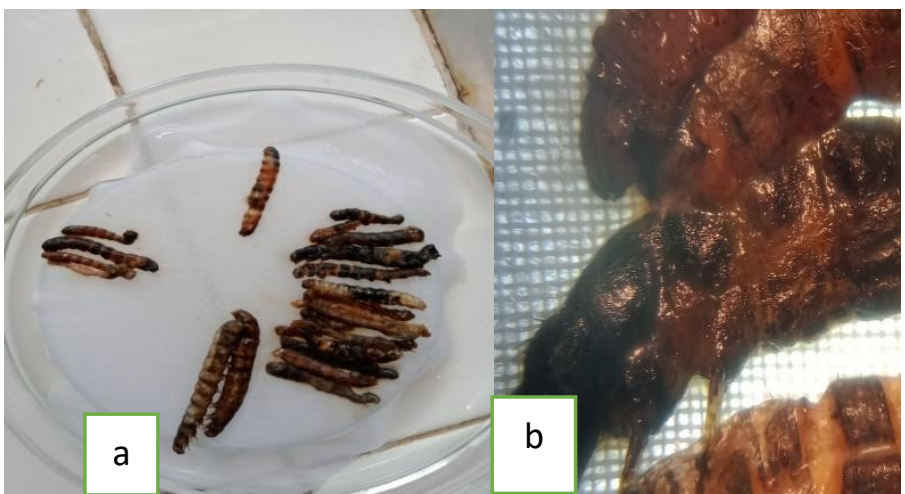

Figure 1. Frugiperda larvae infected with entomopathogenic nematodes (a) seen through a microscope (b) 


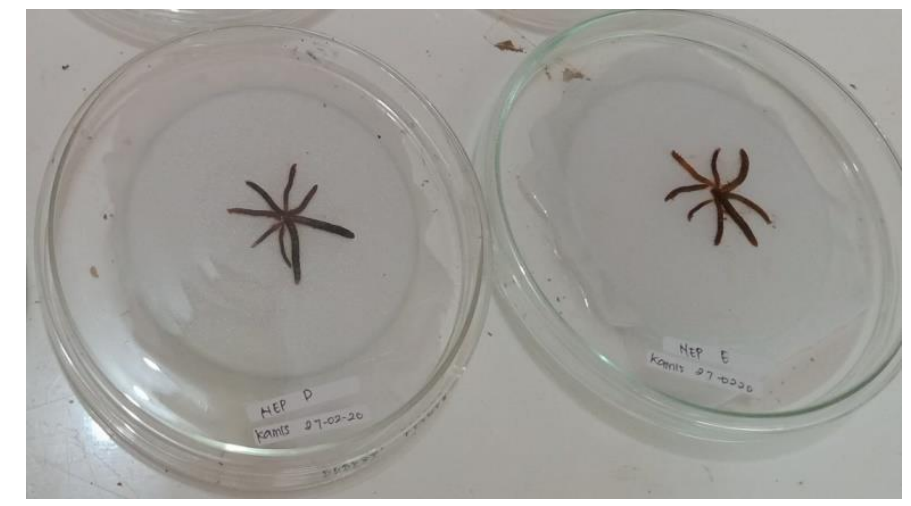

Figure 2. Tenebrio molitor larvae infected with entomopathogenic nematodes

These symptoms are consistent with the results of research by Nugrohorini (2007) that $S$. litura larvae infected with NEP Steinernematidae are immobile and stiff and have discolored cuticles. Another symptom that can be observed is the larvae of $T$. molitor which at first are light brown then turn into caramel brown, the structure of the infected larva's body tissue becomes soft, although the larva's body shape remains intact and does not smell bad.

\section{Entomopathogenic Nematode Identification}

The results of observations based on morphological characteristics showed that the nematodes found were entomopathogenic nematodes of the Steinernematidae family. Steinernematidae nematodes have a long body covered by culticula and non-ciliated, a complete digestive tract in the form of a straight line anterior and posterior anus and a ring of nerves that surrounds the esophagus is the nervous system (Figure $3)$.

The identification results were adjusted based on the description of the entomopathogenic nematodes of the Steinernematidae family according to Tanada and Kaya (1993) and Gaugler (2001). Entomopathogenic nematodes of the Steinernematidae family have common and distinctive morphological features. The head is smooth and unhooked, the tail is short pointed, has a vulva that protrudes outward and is located in the middle, the nerve ring is located anteriorly.

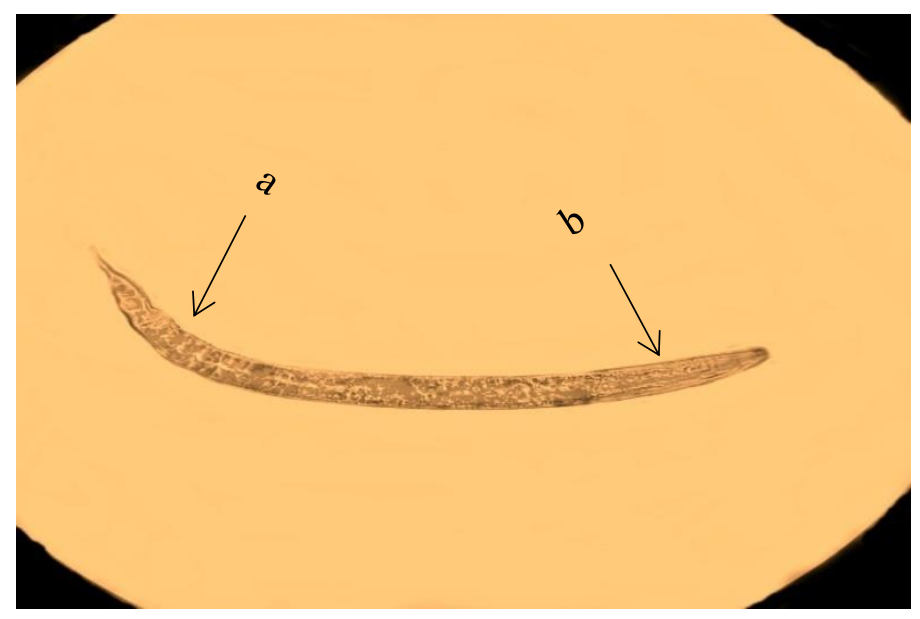


Figure 3. Entomopathogenic nematodes of the Steinernematidae family, tail (posterior) (a) head (anterior) (b), magnification 400x

The results of the identification of entomopathogenic nematodes that infect T. molitor larvae showed blackish brown color in the larval cuticle. In this study, only one type of NEP was found, namely the genus Steinernema, in accordance with Anggraeni's (2003) opinion that two different types of NEP were never found in one test insect. This is presumably due to the specific relationship between the host insect and NEP and the symbiont bacteria of each type of NEP.

Entomopathogenic Nematode Population Density From the calculation of the average population density of NEP in each region, namely in the Kepahiang area there were $15 \mathrm{~T}$. molitor larvae attacked by NEP with an average population density of $9005 \mathrm{NEP} / 5 \mathrm{ml}$ and in the Bengkulu region there were 11 T. molitor larvae attacked by NEP. with an average population density of 6,837 NEP / 5ml. The population density is higher in the Kepahiang area (Figure $4)$.

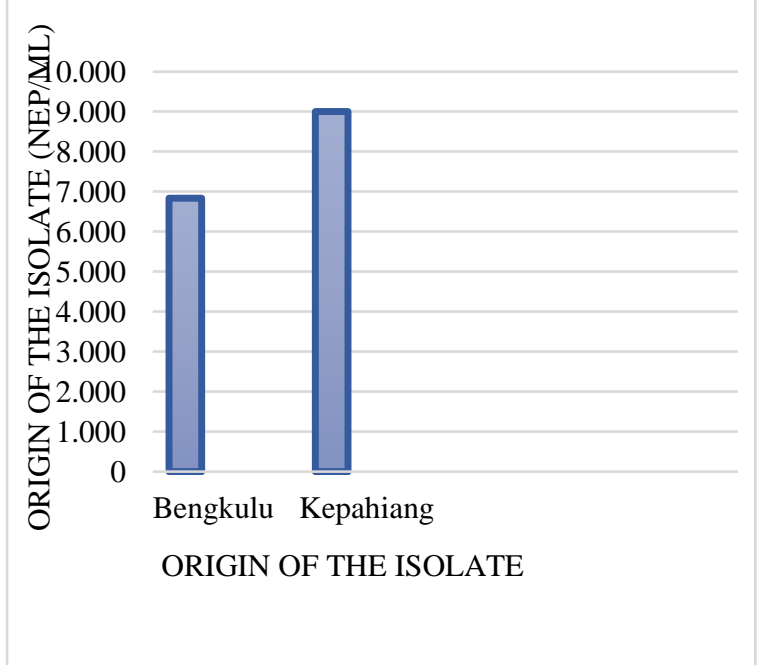

Figure 4. Average entomopathogenic nematode population density
The high nematode population in the Kepahiang area is thought to be because the soil type in the Kepahiang area is Andosol. Broadly speaking, Andosol soil has quite good physical and chemical properties, so that the soil productivity is medium to high. This land is widely used for horticultural or vegetable crops, flowers, plantations and forestry. In general, Andosol soil is blackish in color with a crumbly texture that looks looser and has high organic matter content. The substance contained in it is mostly volcanic ash from volcanic eruptions (Barchia 2009). This was also reported by Nugrohorini (2010), that nematodes cannot live in clayey clay types, because in this type of soil there is no cavity so that oxygen cannot penetrate the soil optimally.

\section{Results of Analysis of Variants}

The results of the analysis of variance showed that the interaction between entomopathogenic nematodes and isolates had no significant effect on all the observed variables. Concentrations showed very significant differences for all the observed variables (Table 1).

\section{Feeding Larvae}

The results of the analysis of variance on observations of larval feeding power showed significantly different results (Table 1). At the time of observation, the feeding power of larvae was calculated by weighing 3 grams of baby corn and weighing it again after 24 hours. 
Table 1. The summary of the results of the F-count analysis of variance at the $5 \%$ level in each observed variable

\begin{tabular}{lcccc}
\hline \multirow{2}{*}{ Observationall variables } & \multicolumn{3}{c}{$\mathrm{f}$-count } \\
\cline { 2 - 5 } & \multirow{2}{*}{ Isolate } & concentration & interaction & \multirow{2}{*}{ KK \% } \\
\hline Larval feeding power & $7.2 \mathrm{~ns}$ & $6.1^{* *}$ & $0.3 \mathrm{~ns}$ & 38.7 \\
Percentage of larval mortality & $0.6 \mathrm{~ns}$ & $8.0^{* *}$ & $1.9 \mathrm{~ns}$ & 29.1 \\
The time of death of the larva & $0.9 \mathrm{~ns}$ & $0.3^{* *}$ & $2.7 \mathrm{~ns}$ & 29.8 \\
\hline
\end{tabular}

Information: $\mathrm{ns}=$ not significantly different,${ }^{*}=$ significantly different,${ }^{* *}=$ very significantly different at the $5 \%$ level

Table 2. Average feeding power of $S$. frugiperda larvae at various concentrations entomopathogenic isolates.

\begin{tabular}{lcc}
\hline \multirow{2}{*}{ Consentration } & \multicolumn{2}{c}{ Feeding Larvae } \\
\cline { 2 - 3 } & $\begin{array}{c}\text { Kepahiang } \\
\text { Isolate }\end{array}$ & $\begin{array}{c}\text { Bengkulu } \\
\text { Isolate }\end{array}$ \\
\hline $200 \mathrm{Jl} / 1 \mathrm{ml}$ & $7.1 \mathrm{a}$ & $6.2 \mathrm{a}$ \\
$400 \mathrm{Jl} / 2 \mathrm{ml}$ & $5.5 \mathrm{a}$ & $5.6 \mathrm{a}$ \\
$600 \mathrm{Jl} / 3 \mathrm{ml}$ & $3.1 \mathrm{~b}$ & $3.9 \mathrm{a}$ \\
\hline
\end{tabular}

Based on the average test with a $5 \%$ BNT level, it shows that the average feeding power of larvae in Kepahiang isolates with a concentration of 400J1 / 2 $\mathrm{ml}$ is significantly different from the feeding power of larvae at a concentration of $600 \mathrm{Jl} / 3 \mathrm{ml}$, while in Bengkulu isolates the average feeding power is not significantly different at every concentration.

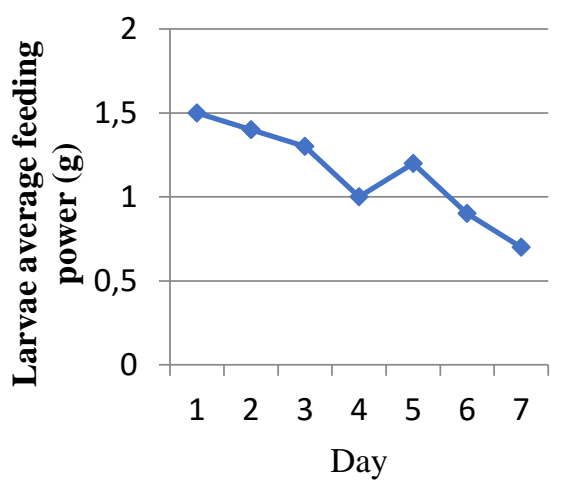

Figure 5. Average feeding power of larvae
Data on the average feeding power of larvae (Figure 5) shows that on day 1 , larvae eat as much as 1.5 grams of baby corn, but on day 2 to day 4 larvae feeding power decreases. This is because the infected larvae move slowly and even tend to stay still, so the larvae are not active in foraging. On the 5th day the average feeding power increased by 1.2 $\mathrm{g}$, this is presumably because the larvae began to move foraging to increase immunity in defense against NEP attacks, in accordance with the statement of Ehlers (1996) that the killing power of NEP against The host insect is determined not only from the NEPbacterial symbiont complex, but also the level of immunity of the host insect. However, on the 6th and 7th day, the average feeding power of the larvae decreased again, from the 3 grams of baby corn given, the larvae only ate 0.7 grams.

The decreased feeding activity of S. frugiperda larvae is caused by disruption of the insect body tissue by the symbiont bacteria produced from NEP as a toxin, causing damage to the digestive tract and destroying the immune system of $S$. frugiperda larvae.

The percentage of mortality and time of death of $S$. frugiperda larvae at various concentrations

Observation of the number of $S$. frugiperda that died was carried out 
every 24 hours for 7 days and was calculated using the percentage mortality formula. Based on calculations using the percentage mortality formula, the concentration of NEP $600 \mathrm{Jl} / 3 \mathrm{ml}$ produced the highest percentage of mortality, namely 100\% with Kepahiang isolates and 93.3\% with Bengkulu isolates. Then followed by the concentration of NEP $400 \mathrm{Jl} / 2 \mathrm{ml}$, namely $80 \%$ with Kepahiang isolates and $73.3 \%$ with Bengkulu isolates. This shows that the greater the concentration of NEP given to $S$. frugiperda larvae will spur the mortality percentage of $S$. frugiperda to increase (Table 3).

Table 3. Average percentage of mortality of $S$. frugiperda larvae at various concentrations and origins of entomopathogenic nematode isolates

\begin{tabular}{ccc}
\hline \multirow{2}{*}{ Concentration } & \multicolumn{2}{c}{ Mortalitas (\%) } \\
\cline { 2 - 3 } & $\begin{array}{c}\text { Kepahiang } \\
\text { Isolate }\end{array}$ & $\begin{array}{c}\text { Bengkulu } \\
\text { Isolate }\end{array}$ \\
\hline $200 \mathrm{Jl} / 1 \mathrm{ml}$ & $60 \mathrm{~b}$ & $46,6 \mathrm{~b}$ \\
$400 \mathrm{Jl} / 2 \mathrm{ml}$ & $80 \mathrm{ab}$ & $73,3 \mathrm{ab}$ \\
$600 \mathrm{Jl} / 3 \mathrm{ml}$ & $100 \mathrm{a}$ & $93,3 \mathrm{a}$ \\
\hline
\end{tabular}

Similar research results were also reported in $S$. exigua larvae that the high concentration of NEP affected the mortality percentage of $S$. exigua (Baharuddin, 2014). Wiludjeng and Sri (2014), reported that with an increase in mortality of Spodoptera sp. Larvae. with each increase in the dose of Steinerma sp. so it can be said that the dose of Steinerma sp. which was applied had a positive effect on the percentage of mortality of larvae of Spodoptera $s p$.

The calculation of the mortality of S. frugiperda larvae showed that there was an increase in mortality from 1 day after application. The highest mortality occurred on the 4 th day after application where 16 S. frugiperda larvae died in Kepahiang isolates and $10 \mathrm{~S}$. frugiperda larvae in Bengkulu isolates. On the 5th to the 7th day, the average number of larvae that died was $2 S$. frugiperda larvae in Kepahiang isolates, while in Bengkulu isolates larvae mortality only occurred until the 6th day (Figure 6)

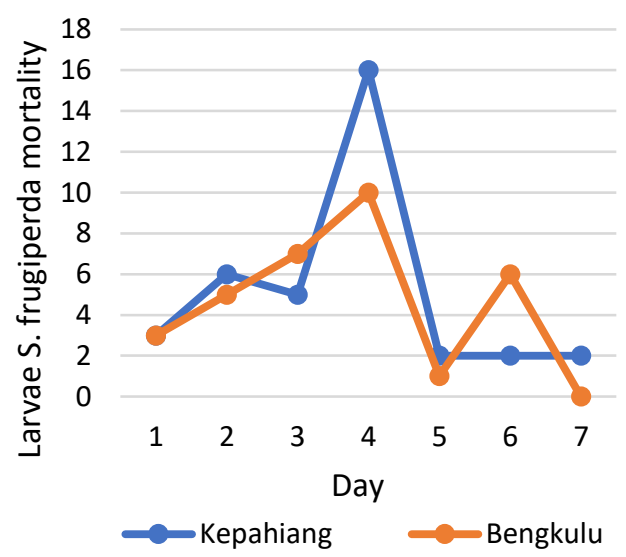

Figure 6. Graph of S. frugiperda larvae mortality

The pathogenicity mechanism of Steinernema sp. begins with the penetration of Steinernema sp. nematodes. into the body of $S$. frugiperda., presumably through natural openings such as the spiracle, mouth, and anus, then ending with the death of S. frugiperda.

The high pathogenicity of Steinernema sp nematodes is thought to be due to Steinernema sp. has a higher resistance to desiccation (drought), as well as the nematode symbiont bacteria Steinernema $s p$. produce more effective enzymes and toxins. Likewise, the higher resistance to the entomopathogenic nematode Steinernema sp. This is supported by the research report of Surrey and Wharton (1995), that several types of entomopathogenic nematodes, namely Steinernema sp. Certain isolates have higher resistance to desiccation than other types of entomopathogenic nematodes, so that this type of nematode 
is more resistant to life and attacks the host. The presumption is that Steinernema sp. contains enzymes and toxins that are more effective than other types of nematodes, it has been reported by Kaya and Koppenhofer (1996) that Steinernema spp. certain can kill the host insect because the symbiont bacteria have enzymes and toxins that are very effective.

Table 4. Average time of death of $S$. frugiperda larvae at various entomopathogenic nematode concentrations

\begin{tabular}{ccc}
\hline \multirow{2}{*}{ Consentration } & \multicolumn{2}{c}{ Time of death (days) } \\
\cline { 2 - 3 } & $\begin{array}{c}\text { Kepahiang } \\
\text { Isolate }\end{array}$ & $\begin{array}{c}\text { Bengkulu } \\
\text { Isolate }\end{array}$ \\
\hline $200 \mathrm{Jl} / 1 \mathrm{ml}$ & $3,9 \mathrm{a}$ & $4,9 \mathrm{a}$ \\
$400 \mathrm{Jl} / 2 \mathrm{ml}$ & $3,7 \mathrm{a}$ & $3,7 \mathrm{a}$ \\
$600 \mathrm{Jl} / 3 \mathrm{ml}$ & $3.1 \mathrm{a}$ & $3,4 \mathrm{a}$ \\
\hline
\end{tabular}

Note: The numbers followed by different letters in the same column show a significant difference in the BNT follow-up test at the $5 \%$ level

Based on the average test with the BNT level of $5 \%$, the mortality rate at the concentration of $200 \mathrm{Jl} / \mathrm{ml}, 400 \mathrm{Jl} / \mathrm{ml}$ and 600Jl / $\mathrm{ml}$ was not significantly different, even though the NEP concentration was added and NEP isolates came from different areas but the results were not different. real, but the concentration of NEP $200 \mathrm{Jl} / \mathrm{ml}$ was able to kill the larvae within 4 days. The relationship between the NEP concentration and the time of death of $S$. frugiperda larvae shows that the higher the NEP concentration at the time of application, the higher the mortality of $S$. frugiperda. It is thought that the more NEP in S. frugiperda's body, the more severe the damage to $\mathrm{S}$. frugiperda's body tissue due to NEP attacks. After S. frugiperda dies, the nematodes will come out and look for new hosts. As reported by Sulistiyanto (1998), Steinerma sp. stay in the host's body for 10-14 days or until death, then the nematodes leave the host's body and look for a new host.

Table 5. Table LC50 and LC75 Spodoptera frugiperda against Entomopathogenic Nematodes

\begin{tabular}{ccc}
\hline Isolate & $L C 50 \%$ & $L C 75 \%$ \\
\hline Kepahiang & $163.5 \mathrm{Jl} / \mathrm{ml}$ & $319.5 \mathrm{Jl} / \mathrm{ml}$ \\
Bengkulu & $186.5 \mathrm{Jl} / \mathrm{ml}$ & $398.7 \mathrm{Jl} / \mathrm{ml}$ \\
\hline
\end{tabular}

Determination of the values of LC50 and LC75 is the determination of the optimal concentration, intended for Steinermatidae spp. effective for controlling S. frugiperda larvae. The results of the NEP petogenicity test on $S$. frugiperda larvae showed that there was an increase in mortality at each treatment concentration. The estimated value of LC50 from probit analysis was $163.873 \mathrm{Jl} / \mathrm{ml}$ in Kepahiang isolates and $186.582 \mathrm{Jl} / \mathrm{ml}$ in Bengkulu isolates, and the magnitude of the LC75 estimated values from probit analysis was $319.5 \mathrm{Jl}$ / $\mathrm{ml}$ in Kepahiang isolates and $398.7 \mathrm{Jl}$ / $\mathrm{ml}$ in Bengkulu isolates.

\section{CONCLUSION}

The results of the isolation of entomopathogenic nematodes from Bengkulu and Kepahiang regions using Tenebrio molitor larvae obtained entomopathogenic nematodes genus Steinernema with an average population sdensity of entomopathogenic nematodes of 9,005 NEP / $5 \mathrm{ml}$ in the Kepahiang region and 6,837 NEP / 5ml in the Bengkulu region. The results of the entomopathogenic nematode virulence test against $S$. frugiperda larvae show that the NEP $200 \mathrm{Jl} / \mathrm{ml}$ concentration can control S. frugiperda in maize (Zea mays), and can kill pests within 4 days. With an LC50 value of 
$163.5 \mathrm{Jl} / \mathrm{ml}$ in Kepahiang isolates and $186.5 \mathrm{Jl} / \mathrm{ml}$ in Bengkulu isolates, while the LC75 values were $319.5 \mathrm{Jl} / \mathrm{ml}$ in Kepahiang isolates and $398.7 \mathrm{Jl} / \mathrm{ml}$ in Bengkulu isolates.

\section{REFERENCES}

Anggraeni, E. D. 2003. Nematoda Entomopatogen pada Beberapa Lahan Palawija dan Hortikultura di Wilayah Bogor dan Cianjur. Skripsi. Fakultas Pertanian, Universitas Pertanian Bogor. Bogor.

Baharuddin, F. 2014. Uji Efektivitas Nematoda Entomopatogen Pada Hama Bawang Merah Spodoptera exigua. Skripsi. Fakultas Pertanian Universitas Semarang. Semarang.

Baliadi, Y. 2011. Pathogenecity, development and reproduction of the entomopathogenic nematode Steinernema sp., in mealworm Tenebrio molitor. Jurnal Agrivita. 33 (3): 240-251.

Barchia, F. M. 2009. Tanah Tropika Agroekoteknologi Lahan Kering. Badan penerbitan Fakultas Pertanian Universitas Bengkulu. Bengkulu

Buurma dan Nurmalinda. 1994. Pestcontrol Practices in Shallot in Brebes.Internal Communication LEHRI/ ATA-395 No.42.

CABI. 2019. Spodoptera frugiperda (Fall Armyworm).

https:/ / www.cabi.org/ISC/fallar myworm. 10 September 2019.

Chaerani, F., M.M. Downes, M.J, and C.T. Griffin. 1995. Pembiakan Massal Nematoda Entomopatogen Serangga
Steinernema dan Heterorhabditis Isolat Indonesia secara In vitro untuk Pengendalian Hama Penggerek Padi secara Hayati. Poster Ilmiah pada Pekan Ilmu Pengetahuan dan Teknologi. Tanggerang.

Djamilah, Nadrawati, dan M. Rosi. 2010. Isolasi Steinernema dari tanah pertanaman jagung di Bengkulu bagian selatan dan patogenesitasnya terhadap Spodoptera litura F. Jurnal Ilmu Pertanian Indonesia. 12(1): 34-39

Djunaedi, A. 2009. Studi Karakter Ekologi Nematoda Entomopatogen Heterorhabditis Isolat Lokal Madura. Jurnal Embryo. 6(1): 1-12.

Ehlers, R. U. 1996. Current and future use of nematodes in biocontrol : practice and comercial aspects with regard to regulatory policy issues. Journal of Biocontrol Science and Technology. 6(1): 303-316.

FAO and CABI. 2019. Community-Based Fall Armyworm (Spodoptera frugiperda) Monitoring, Early Warning and Management. Training of trainers manual, First Edition. 112 pp.

Gauler, R. and H.K. Kaya. 1990. Entomopathogenic Nematodes in Biological Control. CRC Press. Florida.

Kaya, H.K. and Stock, S.P. 1997. Manual of Technique in Insect Pathology. Page 21-27.

Kementerian 2019. Pengenalan Fall Armyworm (Spodoptera frigiperda J. E. Smith) Hama Baru pada Tanaman 
Jagung di Indonesia. Jakarta: Balai Penelitian Tanaman Serealia.

Koster, W.G. 1990. Exploratory Survey on Shallot in Rice-based Cropping System in Brebes. Bul. Penel. Hort. Edisi Khusus XVIII(1):19-30.

Nadrawati., B.R.G. Sempurna dan Z. Agustin. 2019. Identifikasi Hama Baru dan Musuh Alaminya Pada Tanaman Jagung di Kelurahan Sidomulyo Kecamatan Seluma Selatan Kabupaten Seluma. Fakultas Pertanian.Universitas Bengkulu.Bengkulu.

Nugrohorini. 2010. Eksplorasi nematoda entomopatogen pada beberapa wilayah di Jawa Timur. Jurnal Pertanian MAPETA. 12(2): 72-144.

Ria, F. 2014 Nematoda Entomopatogen Indigenous dalam Uji Perbandingan Efikasi Pengendalian Plutella xylostella (Lepidoptera: Plutellidae). Skirpsi. Fakultas Pertanian, Universitas Brawijaya. Malang.

Smart, G. C. 1995. Entomopathogenic nematodes for the biological control of insects. Journal of Nematology.27: 529-534

Sulistiyanto, D. 1998. Prospek dan kemungkinan resiko bioinsektisida nematoda entomopatogen dalam konsep pengendalian hama terpadu.
Makalah seminar FKSIMTI Fakultas Pertanian, Universitas Jember. Jember.

Sulistiyanto, D. 2008. Keselarasan dalam Pemanfaatan dan Pengelolaan Hama Terpadu dengan Memanfaatkan Agens Hayati, Nematoda Entomopatogen dalam Menunjang Sistem Pertanian Berkelanjutan. Universitas Jember. Jember.

Sulistiyanto, D. 2011. Penuntun Praktikum Pembiakan Massal Agens Hayati Nematoda Entomopatogen. Universitas Jember. Jember.

Surrey., M.R., and D.A. Wharton. 1995. Desiccation survival of the infective larvae of the insect parasitic nematodes, Heterorhabditis zealandiaca Poinar. Journal of Parasitology. 25(6): 749-752.

Tanada, and Kaya. 1993. Entomopatogens Nematodes for Insect Controls in IPM System.Academic Press. New York.

Wiludjeng, W. dan S. Rahayuningtyas. 2013. Uji Efikasi Nematoda Entomopatogen Pada Hama Tanaman Cabai. Journal of Agricultural Science. 11(1): 63-66 